\title{
An Evaluation of the Relevance of Current Traditional Leases in Commercial Properties as Compared to Green Leases
}

\author{
Johnson Kampamba*, Simon Kachepa, Milidzani Majingo, Abednico Wadingalo \\ Department of Architecture and Planning, Faculty of Engineering and Technology, University of Botswana, Botswana
}

Received September 18, 2019; Revised March 26, 2020; Accepted April 19, 2020

Copyright $\bigcirc 2020$ by authors, all rights reserved. Authors agree that this article remains permanently open access under the terms of the Creative Commons Attribution License 4.0 International License

\begin{abstract}
Many leading organisations worldwide, have adopted their workplaces as a means to meet a range of financial drivers thereby, secure competitive advantage, through sustainability in built environment. The lack of exploitation of this concept by the commercial property market of Botswana led to the research question for this study. Could it be because the conventional leasing yield the maximum benefits or that what literature and other international policy makers are promoting is something sensational rather than statement of common truth? The purpose of this study was to provide an answer to whether traditional leases are common in Botswana property market as compared to green leases which can be adopted as an alternative sustainable management practice. In realizing the objectives, the study investigated and compared the performance of properties both under green leasing and conventional or traditional leasing by measuring the performance indicators. These performance indicators were operational cost, vacancy rates and utility cost per metre. By utilizing the green design evaluation model, sustainable measures or fixtures were used as input variable in this model whilst profit maximization or returns on investment in commercial properties were treated as variables dependent on operational expenses, vacancy rates and generally costs were the output of this model. From three office nodes of Gaborone purposely selected by the researchers, data was collected through the use of a questionnaire and was analysed using descriptive statistics and overall mean scores were utilized to present the findings. The analysis also indicated that the differences between traditional and green leases in Botswana currently are minimal and therefore, current leases are still relevant to the commercial property market. The implications of the results are that though green leases are sustainable, traditional leases are still relevant and mostly utilised in Botswana's leasing market. The study recommends policy change if green leases are to become more prominence in
\end{abstract}

the rental property market.

Keywords Green Leases, Traditional Leases, Sustainable Development, Green Concept, Botswana

\section{Introduction}

Debate about sustainable development has been intense recently, and the emphasis has been on sustainable development (Collins, Junghans, \& Haugen, 2016; James, 2013). Conferences and workshops have been held ranging from 1992 Agenda 21, Millennium Development Goals of 2000, Millennium summit and Rio de Jainero, the new urban agenda and the current Sustainable Development Goals (Ratcliffe, Stubbs, \& Keeping, 2009; United Nations, 2015; Mudehwe, Chirisa, \& Matamanda, 2016; United Nations, 2017). Much as there has been calls for sustainable development practices worldwide (United Nations, 2015; Mudehwe, Chirisa, \& Matamanda, 2016; United Nations, 2017; Collins, Junghans, \& Haugen, 2016; James, 2013; Ratcliffe, Stubbs, \& Keeping, 2009), no study has been conducted to campare the performance of traditional leases against green leases in the commercial real estate market. Buildings are consumers of building related services such as water, energy and natural gas (Michael , 2008; Khasreen, Banfill, \& Menzies, 2009; Janda, Bright, Patrick, Wilkinson, \& Dixon, 2016; Gerarden, Newell, \& Stavins, 2015). In addition, they also emit gases which lead to global warming (Janda, Bright, Patrick, Wilkinson, \& Dixon, 2016; Khasreen, Banfill, \& Menzies, 2009; Gerarden, Newell, \& Stavins, 2015) hence, a concern in as far as sustainable developement goals are concerned. This study, therefore, seek to establish the difference in performance between traditional leases and 
green leases in commercial real estate properties in Gaborone, Botswana and determine which type of lease is more relevant in the Botswana commercial property market. The objectives of the study were: (1) to establish the extent to which green leases are common in Botswana; (2) to elucidate the difference between traditional leases and green leases; (3) to identify factors that hinder the adoption of green leases in Botswana; and to come up with measures that can help promote the adoption of green leases.

This report is arranged into four major sections; section one covers the introduction to the study, section two the background and previous related studies andsection three describes the methodology that was used in addressing the research question and its objectives. Section four presents the results and analysis of the study and finally the conclusions. This section discussed the introduction and the justification for this research. The next section presents the brief background of the study.

\section{Background and Review of Literature}

The first evidence of lease or rent dates back to $2000 \mathrm{BC}$ whilst in the nineteenth century was marked by a significant proliferation in leasing activity, which was due to the increasing diversity of rented tools (Teodorescu, 2014). According to Bright and Roussac (2012) a lease defines the relationships between the landlords, tenants and operators of tenanted commercial office buildings. The purpose is to protect the interests of the landlord and tenant, as leases are held as the core of this relationship. A lease can be defined as a contract by which one conveys real estate, equipment, or facilities for a specified term and for a specified rent. These contracts include provisions for operating, management and maintenance services (Adnan, Aman, Razali, \& Daud, 2017). Shareena, Sipan, Sapri, Jalil, $\&$ Mohammad (2017) defines green building as a practice of increasing the efficiency with which buildings use resources, while at the same time reducing their impact on human health and the environment, throughout the building's life cycle. Similarly Mudehwe, Chirisa, \& Matamanda (2016) defines green leasing to be a lease that focus on the sustainable practices by the landlord and tenant with the objective of eliminating the disincentives in a commercial lease to reduce energy, water and raw material consumption through the increased recycling as well as use of sustainable materials for tenant improvements.

Oberle \& Sloboda (2010) however, indicates typical commercial leases do a good job of allocating various obligations between the building owner and the tenants, but they seldom address environmental considerations beyond the basics of specifying which party is responsible for payment of utilities. On the other hand, Michael (2008) opined that many leases contemplate the unilateral installation of smart meters for electricity, whilst most do not contemplate similar smart metering for water and natural gas. He further stated that few leases contemplate limiting waste production by the tenant, either in initial fit-out or in ongoing operations, but most leases do not obligate the landlord to recycle with multiple waste streams. As Gerarden, Newell and Stavins (2015) put it, failure of the leases to address environmental issues is significantly increasing resulting in global energy consumption which is expected to grow 30-50 percent over the next 25 years. This will bring with it, in many countries, increased local air pollution, greenhouse gas emissions, and oil consumption which will further lead to higher energy prices (Gerarden, Newell and Stavins, 2015).

However, Janda, Bright, Patrick, Wilkinson, \& Dixon (2016) believes that reductions in emissions on the scale required to stabilize the global climate cannot be achieved without major change in the patterns of energy use across the entire building stock. Changes in this patterns lead to the need for sustainability. 'Green leases' are built on 'green' clauses within the lease which are designed to account for energy efficiency and other sustainability goals (Janda, Bright, Patrick, Wilkinson, \& Dixon, 2016). A green lease has no fixed form, it provides a leasehold structure that will facilitate and support the property being used in an environmentally efficient way. This can relate to any or all of energy use, water management, waste disposal, travel plans and the use of sustainable materials (Bright \& Roussac, 2012).

There is a growing consensus, particularly in developed nations that conventional leasing practices have become obsolete and unsustainable due to a number of challenges associated with them (Blustein, 2013). The challenges include the following: (i) high vacancy levels; (ii) high tenant turnover; (iii) high running costs; and (iv) low returns on investment (Blustein, 2013). This, according to Blustein (2013) have led to an alternative sustaianble measure in lease management called green leasing. In a study that was conducted in Zimbabwe, it was revealed that there are green envelope components which affects the performance of a building and its value while there are some which do not have an effect (Mudehwe, Chirisa, \& Matamanda, 2016). The broader perspectives, however, focuses on matters such as building management, waste disposal, transport, catering and caretaking services that may have a 'green' element (Dixon, Bright, Axon, Janda, \& Kolokotroni, 2012).

The potential value of implementing green leases and challenges in applying them has been umdertaken in various studies (Mudehwe, Chirisa, \& Matamanda, 2016; Adnan, Aman, Razali, \& Daud, 2017; Wiley, Benefield, \& Johnson, 2010; Collins, Junghans, \& Haugen, 2016). Green leases are widely adopted and have significantly been incorporated in commercial properties with increase in participation by various stakeholders as they yield many 
benefits (Modu, Usman, Bulama, \& Habib, 2014). In addition, Senn (2012) noted that the problem that needs to be researched comes from the lack of exploitation on green leases although they may have an influence on returns on investment in commercial properties.

\subsection{Green Leases vs Traditional Leases}

Literature indicate that there is no standard definition of what a green lease is, however there are several unstandardized meanings. According to Brooks (2008) a green lease seeks to remove disincentives in a commercial lease to reduce energy, water and raw material consumption, increased recycling, as well as the use of sustainable materials in tenant improvements, and encourages sustainable practices by both the landlord and the tenant.

A green lease is commonly known as a lease that seeks to reduce the environmental impact of commercial buildings, such as reducing the greenhouse gas emissions by reducing demand for fossil fuels through increased energy efficiency (Michael, 2008). In other countries, the green lease is referred as to, energy-aligned, or energy-efficient or at times a high performance leasing, Table 1 below highlights the clauses that are typically found in the two types of leases.

Based on the comparative analysis in Table 2, it is clear that there a number of differences that exist between the two leases.

Table 1. Clauses common in both green and traditional lease

\begin{tabular}{|l|c|c|}
\hline Clauses that are common both leases & Traditional leases & Green leases \\
\hline Environment impact management plan & $\mathrm{x}$ & $\sqrt{ }$ \\
\hline Sustainability statement plan & $\mathrm{x}$ & $\sqrt{ }$ \\
\hline Data sharing statement & $\mathrm{x}$ & $\sqrt{ }$ \\
\hline Outgoings statement & $\sqrt{ }$ \\
\hline Assignment and subletting statement & $\sqrt{ }$ \\
\hline Rent review statement & $\sqrt{ }$ & $\sqrt{ }$ \\
\hline Repair and alteration statement & $\sqrt{ }$ \\
\hline
\end{tabular}

Source (Brookes, 2008; Bright \& Dixie, 2014; Blustein, 2013)

Table 2. Comparative summary of leases

\begin{tabular}{|c|c|c|}
\hline Aspect & Green leasing & Conventional Leasing \\
\hline Paradigm/ school of thought & Green agenda & Capitalism \& free market economy \\
\hline Business relationship & $\begin{array}{ll}\text { - } & \text { Long term } \\
\text { - } & \text { Business Partners with shared vision } \\
\end{array}$ & $\begin{array}{ll}\text { - } & \text { Short term } \\
\text { - } & \text { Commercial partners with diverse vision } \\
\end{array}$ \\
\hline Tenant retention & - High tenant retention & High tenant turnover \\
\hline Environmental externalities & Positive environmental externalities & - $\quad$ Negative environmental footprint \\
\hline Outcomes & $\begin{array}{l}\text { - Low carbon footprints } \\
\text { - Increased building occupancy } \\
\text { - Defined tenant/landlord responsibilities and } \\
\text { obligations }\end{array}$ & $\begin{array}{l}\text { - } \quad \text { High carbon footprints } \\
\text { - } \quad \text { High tenant turnover hence voids } \\
\text { Exploitative contracts with win-lose } \\
\text { outcomes }\end{array}$ \\
\hline $\begin{array}{lll}\begin{array}{l}\text { Operating } \\
\text { overheads }\end{array} & \text { costs } & \text { and } \\
\end{array}$ & - Low operating costs & - High operating costs \\
\hline Profitability & - $\quad$ Marginally higher profits levels & Marginally lower profit levels \\
\hline
\end{tabular}

Source: (Mudehwe, Chirisa, \& Matamanda, 2016; Brookes, 2008; Bright \& Dixie, 2014; Blustein, 2013) 


\subsection{Factors Which Hinders the Adoption of Green Leases}

It is widely recognized that there are serious barriers and disincentives to the implementation of energy efficient measures in tenanted commercial space. Amongst them are; poor communication (Dixon, Bright, Axon, Janda, \& Kolokotroni, 2012); financial disincentives and insufficient research (Kibert, 2016); cost of capital improvements (James, 2013); costs transferred to tenants as a barrier to the adoption of green leases (Sayce, Sundberg, Parnell, \& Cowling, 2009); long pay back periods of some types of improvements; indifferent tenants; Inability to pass through the current portion of amortized landlord's capital costs; lack of skill or knowledge; no knowledge of an achievable target; no leadership, compulsion or incentive from government; no measurement systems in place to determine existing consumption; lack of capital; lack of building operational expertise; and/or restrictions in the lease (Brooks, 2008).

\subsection{Benefits of Green Leasing}

In return, a range of benefits are attributed to green buildings or associated with features common in green buildings. Owners, developers and occupiers may obtain benefit from the diverse range of subsidies and tax benefits. For tenants, these are related to reduced operating costs of the building (mainly associated with energy and other utility savings), improved productivity of the occupying business (associated with reduced staff turnover and absenteeism, inter alia), possible tax and other incentives and other competitive advantages linked to marketing and image benefits. Other benefits may include increased ability to recruit and retain employees, higher employee morale, fewer sick days, and increased employee productivity (Colleta, 2009; Blustein, 2013; Duncan, 2010). Research has therefore, showed that by adopting green leasing practices, the energy efficiency gap can be filled, and utility consumption in offices is significantly reduced with potential for both landlords and tenants to realize significant savings. Green leases can ultimately, be adopted as a tool to improve energy efficiency, and achieve a high-performing building. This section has looked at the background and previous related studies, benefits and factors hindering the adoption of green leases. The next section discusses how the data was obtained and analysed.

\section{Research Methodology}

The study was conducted in Gaborone's commercial property market by administering a questionnaire to tenants, landlords and property managers. A questionnaire was chosen because it has the ability to reach a larger number of respondents at least cost and within a shorter period of time. A questionnaire was administered to three office nodes in Gaborone namely, Central business district (CBD), Kgale Mews and Fairgrounds. Due to time constraints, 58 questionnaires were administered randomly in the three zones and only 46 were returned translating into $79 \%$. This response rate was high and acceptable due to the collection strategy that was adopted. According to Johnson \& Owens (2009), 40 to 60 per cent may generally be expected as a response rate range for written surveys. This could be attributed to a smaller sample size that was used. Table 3 below highlights the number of questionnaire that was distributed in the three zones.

Table 3. Study area analysis

\begin{tabular}{|c|c|c|}
\hline Location & $\begin{array}{c}\text { Questionnaires } \\
\text { distributed }\end{array}$ & $\begin{array}{c}\text { Total Questionnaires } \\
\text { collected }\end{array}$ \\
\hline CBD & 23 & 17 \\
\hline Kgale Mews & 18 & 14 \\
\hline Fairgrounds & 17 & 15 \\
\hline Total & 58 & 46 \\
\hline
\end{tabular}

\section{Data Presentation and Analysis}

In prior sections, the study discussed the literature that relates to the research topic and the methodology in which data was collected. The objective of this section is to present and analyse the data collected from users of commercial office spaces.

\subsection{Background Information about Respondents}

This section of the study presents background information of the tenants and owners in the three designated research areas of Gaborone (Fairgrounds' office park, Kgale mews and the CBD). A descriptive analysis was used to present the survey results on the background information of tenants and owners of these commercial office spaces. Table 4 below presents the results.

Table 4. Demographical data of respondents

\begin{tabular}{|l|c|c|}
\hline $\begin{array}{l}\text { Variables used to get } \\
\text { demographical data }\end{array}$ & Frequency (n) & $\begin{array}{c}\text { Percentage } \\
(\mathbf{\%})\end{array}$ \\
\hline Gender of respondent & 22 & 47.8 \\
Male & 24 & 52.2 \\
Female & $\mathbf{4 6}$ & $\mathbf{1 0 0 \%}$ \\
\hline Age range of the respondent & & \\
21-31 years & 23 & 50 \\
32-42 years & 20 & 43.5 \\
42+ years & 3 & 6.5 \\
& $\mathbf{4 6}$ & $\mathbf{1 0 0 \%}$ \\
\hline Occupation of the respondent & 10 & 21.7 \\
Administration & 16 & 34.8 \\
Administration and finance & 14 & 30.4 \\
Any real estate field & 6 & 13.1 \\
Top management & $\mathbf{4 6}$ & $\mathbf{1 0 0 \%}$ \\
\hline Classification of space use & & 58.7 \\
Tenant & 27 & 30.4 \\
Owner & 14 & 8.7 \\
Owner's Agent & 4 & 2.2 \\
Others & 1 & $\mathbf{1 0 0 \%}$ \\
\hline
\end{tabular}


Table 4 above shows responses from a sample of $n=46$. The data shows that most of the respondent $(52.2 \%)$ that participated in the study were Females. It is also clear that the majority $(83.5 \%)$ of the respondents were in the age range of 21-42 years. These findings are in line with Botswana's population and demographic. Moreover, the data reflects that the occupation of the majority of the respondents $(86.9 \%)$ were in administration and finance, and real estate whereas only $13.1 \%$ were from Top Management. The majority of respondents (89.1\%) and the remaining (11.9\%) were Owner's Agent and Others

\subsection{The Extent to which Green Leases Are Common in Botswana}

Respondents were asked to indicate the level of agreement using a five point Likert scale of 1 being strongly disagree (SD) and 5 being strongly agree (SA). In accordance with objective one, the question was formulated to determine the level of awareness of green leasing in the Botswana commercial property market. They were asked to indicate if green leasing is common in the commercial property market of Botswana as shown in Figure 1 . The majority of respondents $(50 \%)$ were neutral and the other $50 \%$ disagreed/strongly disagreed with the statement that green leases were common in the commercial property market of Botswana. This implies that they all disagreed with the statement that green leases are common in the commercial property market of Botswana. These results are not different from other studies (Brooks, 2008; Adnan, Aman, Razali, \& Daud, 2017; Mudehwe, Chirisa, \& Matamanda, 2016; Wiley, Benefield, \& Johnson, 2010) that have been carried out before.

In addressing objective 2, which was to establish the difference between traditional leases and green leases and their significance to the performance of commercial properties. Respondents were asked to indicate the clauses that they have in their leases and indicate the type of lease that they have signed. Table 5 illustrates the clauses that are commonly used in the two leases.

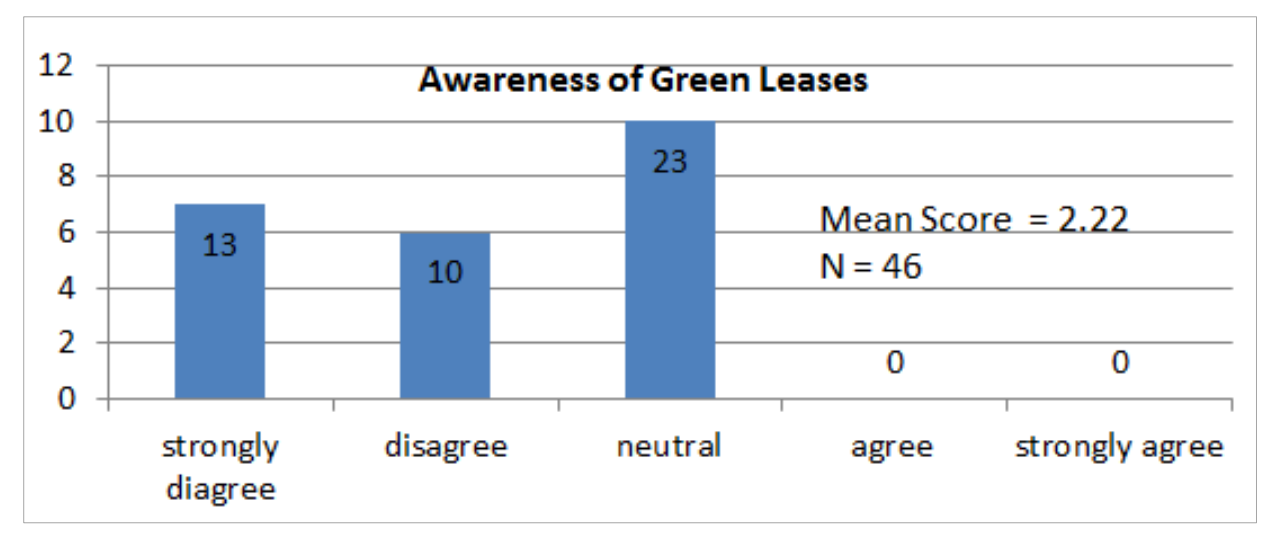

Figure 1. Awareness of green leases in the commercial property market

Table 5. Clauses common in both green and traditional leases

\begin{tabular}{|l|c|c|}
\hline Clauses that are common both leases & Traditional leases $\mathbf{n}=\mathbf{4 1}(\mathbf{8 9 . 1} \%)$ & Green leases n=5 (10.9\%) \\
\hline Environment impact management plan & No & Yes \\
\hline Sustainability statement plan & No & Yes \\
\hline Data sharing statement & No & Yes \\
\hline Outgoings statement & Yes & Yes \\
\hline Assignment and subletting statement & Yes \\
\hline Rent review statement & Yes & Yes \\
\hline Repair and alteration statement & Yes & \\
\hline
\end{tabular}


It was clear that the majority of the respondents (89.1\%) have signed for a traditional lease and only $10.9 \%$ has signed for green lease. This finding is line with what Mudehwe, Chirisa, \& Matamanda (2016) had noted in their study, where it was discovered that there were very few green leases in the commercial property market in Zimbabwe. It is also noted from the findings of this study that; traditional leases did not have clauses pertaining to environment impact management plan, sustainability statement, and data sharing statement. The common clauses in the two leases were outgoings statement, assignment and subletting statement, rent review statement and repairs and alterations statement. From the results that were obtained, it was clear that they were consistent with findings in other studies (Brookes, 2008; Bright \& Dixie, 2014; Blustein, 2013). These were further supported by what Mudehwe, Chirisa, \& Matamanda (2016) had stated that the underlying foundations of any green lease are: (i) structure of the rent and operating expenses; (ii) building improvements that are initiated by the tenants; (iii) adherence to the principles of sustainable development; (iv) appropriate use and disposal of hazardous materials; (v) recycling; and (vi) environmental preservation and conservation plans.

The idea was to find out whether any of these measures exist under the current leasing structures then further identify performance indicators under current leasing conditions which will then be compared to performance indicators realized under green leasing then use the difference to identify the significance and make conclusions. Table 6 summarizes the responses to this question.

It is evident from Table 6 that most of the sustainable features were not available in the buildings that were surveyed thus implying that green leases were far-fetched, an observation that was noted in previous similar studies (Mudehwe, Chirisa, \& Matamanda, 2016; Brookes, 2008; Bright \& Dixie, 2014; Blustein, 2013).

Table 6. Availability of sustainable features in the building

\begin{tabular}{|l|c|c|c|c|}
\hline Variables asked & No & Yes & $\mathrm{N}$ & Percent \\
\hline LED lighting & $100.0 \%$ & $.0 \%$ & 46 & $100.0 \%$ \\
\hline $\begin{array}{l}\text { Day lighting / occupancy } \\
\text { sensors }\end{array}$ & $92.3 \%$ & $7.7 \%$ & 46 & $100.0 \%$ \\
\hline Maximised natural daylight & $96.2 \%$ & $3.8 \%$ & 46 & $100.0 \%$ \\
\hline Building automation system & $92.3 \%$ & $7.7 \%$ & 46 & $100.0 \%$ \\
\hline Storm water retention & $92.3 \%$ & $7.7 \%$ & 46 & $100.0 \%$ \\
\hline Low flow water fixtures & $84.6 \%$ & $15.4 \%$ & 46 & $100.0 \%$ \\
\hline On site renewable energy & $92.3 \%$ & $7.7 \%$ & 46 & $100.0 \%$ \\
\hline $\begin{array}{l}\text { Use of drought resistant } \\
\text { plants for landscaping }\end{array}$ & $96.2 \%$ & $3.8 \%$ & 46 & $100.0 \%$ \\
\hline
\end{tabular}

The next part was to discuss the performance indicators in the commercial office space.

Respondents were asked to indicate the operational expenses for the building that they were occupying.

The majority of the respondents $(79 \%)$ indicated that their expenses ranged from $20 \%$ up to $30 \%$ and above and only $21 \%$ had operating expenses below $10 \%$. This is an indication of an absence of sustainable property development and management practices. These expenses are not different from those that were found in previous studies (Brookes, 2008; Bright \& Dixie, 2014; Blustein, 2013; Mudehwe, Chirisa, \& Matamanda, 2016).

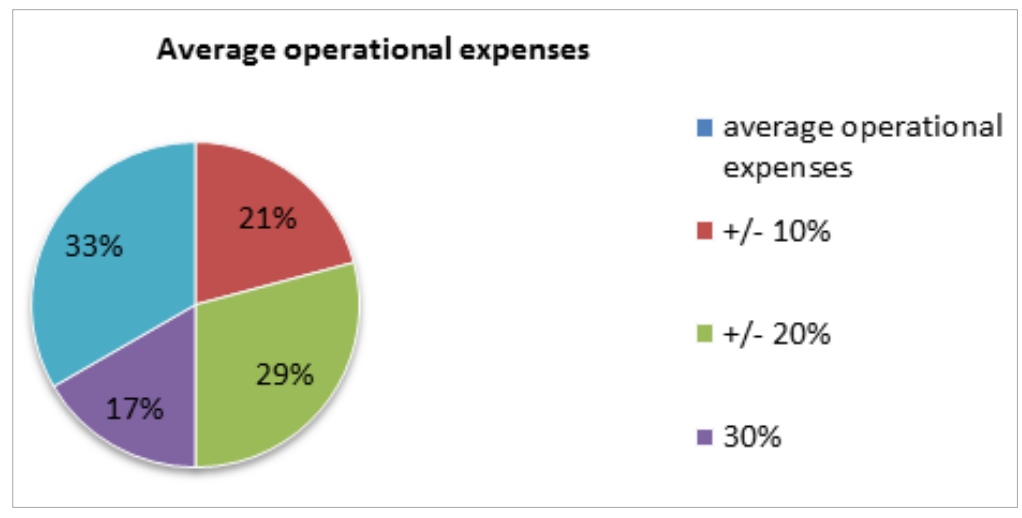

Figure 2. Average operational expenses 
Table 7. Factors hindering the adoption of green leases

\begin{tabular}{|l|c|c|c|c|c|c|c|c|}
\hline Variables & NS & LS & N & S & VS & MS & Total & Comments \\
\hline Fear of rent increase & 11.5 & 3.8 & 19.2 & 26.9 & 38.6 & 3.77 & 100 & Significant \\
\hline No measurement systems & 33.3 & 8.3 & 16.2 & 20.8 & 20.8 & 2.87 & 100 & Neutral \\
\hline Lack of capital & 7.7 & 11.5 & 11.5 & 26.9 & 42.3 & 3.84 & 100 & Significant \\
\hline Lack of operational expenses & 29.2 & 0 & 12.5 & 37.5 & 20.8 & 3.21 & 100 & Neutral \\
\hline Lack of knowledge of achievable target & 4.2 & 0 & 29.2 & 25 & 41 & 4.00 & 100 & Significant \\
\hline Lack of restrictions & 33.3 & 12.5 & 29.2 & 20.8 & 4.2 & 2.75 & 100 & Neutral \\
\hline Long pay back periods & 25.0 & 12.5 & 25.0 & 29.2 & 12.5 & 3.04 & 100 & Neutral \\
\hline Lack of government incentives & 3.85 & 3.85 & 19.2 & 3.85 & 69.2 & 4.31 & 100 & Significant \\
\hline
\end{tabular}

In addressing Objective 3, respondents were asked to identify factors that hinders the adoption of green leases in commercial properties using a five point Likert scale of 1 being not significant and 5 most significant. In evaluating the responses, the following scoring criteria was used. If $\mathrm{X}$ $<1.49$ then the factor is 'Not Significant (NS)'; if X $\geq 1.5$ but $\leq 2.49$ then the factor is 'Less Significant (LS)'; if $X$ $\geq 2.5$ but $\leq 3.49$ then the factor is 'Neutral (N)'; if $\mathrm{X} \geq 3.5$ but $\leq 4.49$ then the factor is 'Significant (S)'; if $X>4.5$ then the factor is 'Very Significant (VS)'. Table 7 below is illustration of the results.

These factors were responded to by both owners and tenants in the various areas where the study survey was conducted. The most significant hindrance to adoption of green leasing is the lack of incentives by government (4.31), followed by lack of knowledge of achievable targets (4.00); lack of capital (3.84) and fear of rental increment (3.77). These results are in line with what Brooks (2008) had noted. On the contrary, long payback periods may also be said to be very significant factor although it does not have the highest frequency. This is due to the fact that long pay back period is a factor that may affect mainly owners of the buildings but due to their minimal participation, the results showed low frequency. Leadership by government appears to be the most significant hindrance to the green leasing adoption of Botswana together with the capital factor. This is in accordance with the view that Adnan, Aman, Razali, \& Daud, (2017) hold that cost or financial aspects are the main barriers as compared to other barriers. They further elaborated that the challenge is that the initial incurred cost is perceived to be higher when compared to conventional practice. However, this should not necessarily be the case as the reduction of energy consumption, reduction of water consumption and the use of recycled materials should be the driving force hoped to be achieved by both tenants and landlords.

In addressing Objective 4, to identify if any, the incentives that might help promote the adoption of green leases. For this objective the respondents were required to fill in an open ended question on what they considered could be done to encourage the adoption of green leasing in the commercial property market of Botswana. Figure 3 below is the illustration of the responses. 


\section{Incentives to encourage adoption of Green leasing}

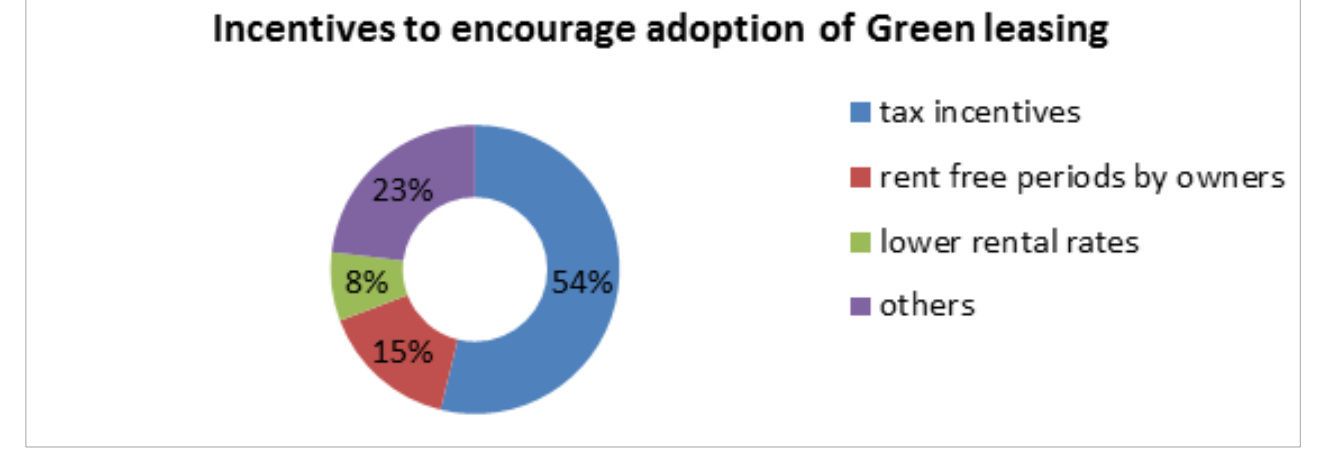

Figure 3. Incentives to encourage green leasing

It showed that $54 \%$ of the respondents indicated that 'if there could be tax incentives for green leased properties many could adopt green leasing'. Other factors that identified included lower rental rates $(8 \%)$ and rent free periods $(15 \%)$ and other incentives $(23 \%)$ otherwise summarized as "others" in this study which included "Assistance programmes regulated by real estate councils"; "Government to set and monitor property owners' operational practices". Green leases are not commonly used in Botswana as most of the real estate market is not equipped on green leases as seen in Figure 3.

\section{Conclusions}

The concept of green leasing has developed to be a global discipline in commercial industry in the world. Botswana as a developing country should work towards the adoption of green leasing as it yields many benefits which will lead to environmental, social, and economic benefits. These benefits, are equally in line with the Botswana's transformational agenda of the vision 2036. The implications of the findings are that developers in Botswana will continue to develop unsustainable buildings if measures to adopt sustainability are not formulated and implemented. In addition, the government should create "sustainability" annual budget to fund innovation projects and provide government schemes to help stakeholders to commit to green practices in built environment. Considering the climatic condition of Botswana, the government should formulate building policies that adopts green concepts and encourages the use of solar energy in commercial buildings. Other measure includes; the creation of a green building Council which will promote and regulate green practices and the involvement of academia in research centred on sustainable development practices.

\section{REFERENCES}

[1] Adnan, Y. M., Aman, N. U., Razali, M. N., \& Daud, M. N.
(2017). The implementation of green lease practices for office building in Kuala Lumpur, Malaysia. Property Management, 35(3), 306-325. Retrieved from https://doi.org/10.1108/PM-12-2015-0067 on 4/09/2017.

[2] Blustein, S. (2013). Commercial leases: a legal instrument to deliver higher productivity of green commercial buildings. Queensland University of Technology.

[3] Bright, S., \& Dixie, H. (2014). Evidence of green leases in England and Wales. International Journal of Law in the Built Environment, Vol. 6 Iss, 6-20.

[4] Bright, S., \& Roussac, C. A. (2012). Improving environmental performance through innovative commercial leasing; An Australian case study. International Journal of Law in the Built Environment Vol. 4 No. 1, 7-22.

[5] Brooks, S. M. (2008). Green Leases: The Next Step in Greening Commercial Buildings. Real Property Association of Canada, 1-25.

[6] Colleta, D. G. (2009). Green leasing:Implementing sustainability concepts in commercial leases. uarterly \& Urban Development Journal, 1st Quarter, 15-23.

[7] Collins, D., Junghans, A., \& Haugen, T. (2016). Green leasing in theory and practice: A study focusing on the drivers and barriers for owners and tenants of commercial properties. Centre for Real Estate and Facilities Management,Norwegian University of Science and Technology, 1-12.

[8] Dixon, T. J., Bright, S. J., Axon, C. J., Janda, K. B., \& Kolokotroni, M. (2012). Building communities: reducing energy use in tenanted commercial property. Building Research \& Information 40(4), , 461-472.

[9] Duncan, W. (2010). Green leases: becoming a Reality. Australian Property Law Journal, 19 (1):, 1-11.

[10] Gerarden , T., Newell, R., \& Stavins, R. (2015). Deconstructing the energy efficiency gap: conceptual framework and evidence. American Economic Review, 105(5), 183-186. Retrieved fromhttps://econpapers.repec.o $\mathrm{rg} /$ article/aeaaecrev/v_3a105_3ay_3a2015_3ai_3a5_3ap_3 a183-86.htm on $5 / 8 / 2018$.

[11] James, D. (2013). Greening the traditional commercial lease: Building a case for sustainable commercial real estate through economically profitable green leases. Drake Law Review Voule 61, 884-911.

[12] Janda, K. B., Bright, S., Patrick, J., Wilkinson, S., \& Dixon, 
T. J. (2016). The evolution of green leases: towards inter-organisational environmental governance. Building Research \& Information, 44(5-6), 660-674.

[13] Johnson, T., \& Owens, L. (2009). Survey Response Rate Reporting in the Professional Literature. American Association for Public Opinion Research-Survey Research Methods, 127-133.

[14] Khasreen, M. M., Banfill, P. F., \& Menzies, C. (2009). Life cycle assessment and the environmental impact of buildings: a review. Sustainability, 1, 674-701. Retrieved from www.mdpi.com/2071-1050/1/3/674/pdf on 14/08/2017.

[15] Michael , B. S. (2008). Green Leases and Green Buildings. Probate \& Property, 23-26.

[16] Modu, M., Usman, A., Bulama, K., \& Habib, G. A. (2014). The Impact of BREEAM Building's Sustainability Rating Criteriaon The Value of Private Housing in London. International Journal of Basic and Applied Science, 169-180.

[17] Mudehwe,, R., Chirisa, I., \& Matamanda, A. R. (2016). Green Leasing in Zimbabwe: Lessons from Harare's Commercial Property Market. International Journal of Real Estate Studies, Volume 10, 12-24.
[18] Oberle, K., \& Sloboda, M., (2010). The importance of 'greening' your commercial lease. Real Estate Issues, $32-41$.

[19] Ratcliffe, J., Stubbs, M., \& Keeping, M. (2009). Urban planning and real estate development (3rd ed.). USA: Routledge.

[20] Senn, M. A. (2012). Negotiating Green Leases. Real Estate Finance, 3-9.

[21] Teodorescu, C. D. (2014). The Leasing - Evolutions and Trends. Economic Insights - Trends and Challenges Vol.III (LXVI), 85-92.

[22] United Nations. (2015). Transforming our world: the 2030 agenda for sustainable development. New York: United Nations. Retrieved fromhttps://sustainabledevelopment.un. org/.../21252030\%20Agenda\%20for $\% 20$ Sustainabl..on $4 / 8 / 2018$.

[23] United Nations. (2017). Sustainable developement goals report. New York: United Nations. retrieved from sdgactioncampaign.org/wp.../07/TheSustainableDevelopm entGoalsReport2017.pdf on 4/08/2018.

[24] Wiley, J. A., Benefield, J. D., \& Johnson, K. H. (2010). Green design and the market for commercial office space. Journal of Real Estate Finance \& Ecomonics, 44, 228-243. 